\title{
PETAL GROWTH PHYSIOLOGY OF CUT ROSE FLOWERS: PROGRESS AND FUTURE PROSPECTS
}

\author{
Takanori HORIBE*, Kunio YAMADA \\ College of Bioscience and Biotechnology, Chubu University \\ Kasugai 487-8501, Japan
}

Received: January 2017; Accepted: April 2017

\begin{abstract}
Roses are the most important crop in the floriculture industry and attract both pollinators and human admirers. Until now, a lot of research focusing on postharvest physiology including flower senescence has been conducted, leading to improvement in vase life. However, few studies have focused on the physiology of petal growth, the perception of light by petals, and the relationship between petal growth and environmental conditions. Regarding roses, whose ornamental value lies in the process of blooming from buds, it is also important to understand their flowering mechanisms and establish methods to control such mechanisms, as well as focus on slowing the aging process, in order to achieve high quality of postharvest cut roses. Elucidation of the mechanisms of rose flower opening would contribute to enhanced quality and commercial production of floricultural crops as well as greatly advance basic scientific knowledge regarding plant biology. In this review, we describe the progress and future prospects in the study of petal growth physiology of cut roses.
\end{abstract}

Key words: Petal morphology, sugar metabolism, Rosa, circadian rhythm, postharvest

\section{INTRODUCTION}

The rose (genus Rosa) holds an important position in the ornamental flower industry. Roses can usually be found as cut flowers in vases or growing in gardens. Humans are said to have been cultivating roses since before the Common Era, making it one of the most familiar and cherished flowers known to mankind in recorded history. Initially used as a fragrance and medicinal purposes, the rose eventually came to be appreciated as an ornamental flower. In the Northern Hemisphere alone, there are approximately 150 species of roses growing in the wild. While there may be tens of thousands of cultivars grown to date, only 8-20 of these are involved in the breeding of the four main genealogical lines presently being cultivated (Bendahmane et al. 2013). Nowadays, cut flower cultivars are becoming more diverse, ranging from the more traditional varieties with tall, pointy petals to those with rounded, cup-shaped petals; old-rose-like quarterbloom petals; or single-petal flowers.
The quality of a cut flower is contingent upon the external characteristics of the plant such as color, length, volume, freshness, and fragrance as well as its perishability, which is determined by the duration of these aforementioned conditions. In particular, vase life is a critical factor in determining the market value of cut flowers. However, because it takes a few days before cut flowers produced by farmers reach consumers via retailers, aging progresses in the meantime. As a result, most cut flowers will no longer be suitable for ornamental purposes within a week or so, making it difficult to enjoy them for a long time. Factors implicated in shortening the life expectancy of cut flowers include aging, detachment and withering of tissues by ethylene generation, obstruction of vessels because of bacterial propagation (and thus poor water absorption), and deficiency in saccharides that act as osmoregulators and respiratory substrates (Durkin 1979; Burdett 1970; De Stigter 1980; Macnish et al. 2010; Reid 1989; van Doorn 1997). Ethylene, a phytohormone, is a key player involved in the aging of many cut flowers. Consequently, numerous studies 
have aimed to suppress or inhibit ethylene generation during the blooming of cut flowers to slow down the aging process (Ichimura \& Shimizu-Yumoto 2007). In rose flower, it has been reported that ethylene regulate flower opening and petal expansion as well as senescence (Ma et al. 2006; Ma et al. 2008; Tan et al. 2006). The relationship between flower opening and hormones has been reviewed recently by van Doorn \& Kamdee (2014).

As a result of continued efforts to improve the quality of cut flowers, agents such as ethylene inhibitors have been developed, ensuring long-lasting quality of harvested cut flowers. However, many of these studies investigated decelerating the aging process. Regarding roses, whose ornamental value lies in the process of blooming from buds, it is also important to understand their flowering mechanisms and establish methods to control such mechanisms, as well as focus on slowing the aging process, in order to achieve high quality of postharvest cut roses.

\section{PETAL GROWTH AND FLOWER OPENING}

The process of rose flower bud development and subsequent flower opening is irreversible petal growth and reflection in which existing cells expand and fresh and dry weights (DW) increase (Reid \& Evans 1986; Evans \& Reid 1988; Faragher et al. 1984). In Gaillardia $\times$ grandiflora, cell division of the petals seems to stop at a much early stage of flowering, with no increase in the number of abaxial epidermal cells (Koning 1984). In carnation flowers, the amount of DNA in the petals does not increase once petals emerge from the calyx, suggesting that cell division also stops at an early stage (Kenis et al. 1985). These findings indicated that petal growth as it relates to flower opening mainly depends on cell expansion. Cell division in rose petals almost stops while petals are still covered by the calyx (Roberts et al. 2003; Yamada et al. 2009 c), suggesting that rose petal growth associated with flower opening may indeed depend on cell expansion. During flower opening, large amounts of soluble carbohydrates accumulate in petals (van Doorn et al. 1991; Ichimura et al. 2003). Many studies have reported on the application of sugars in extending the vase life of cut flowers (Paulin 1979; Paulin \& Jamain 1982; Ichimura et al. 2003). Paulin and Jamain (1982) and Ichimura et al. (2003) demonstrated that sucrose treatment increased the vase life of cut carnations and roses, suggesting that soluble carbohydrates play an important role in regulating osmotic pressure in petal cells (Fig. 1). Sugar accumulation in petal cells reduces petal water potential, thereby promoting water influx for cell expansion, which may lead to flower opening (Ho \& Nichols 1977). In tulip petals, glucose and fructose accumulate mainly in the vacuole (Wagner 1979). In addition to the vacuole, soluble carbohydrates accumulate in the apoplast in some sink organs, such as tomato fruits (Damon et al. 1988) and sugarcane stalks (Welbaum \& Meinzer 1990). Flowers are also sink organs, and particularly, carbohydrates accumulate in the apoplast of rose petal cells (Yamada et al. 2009b). To accelerate water influx into cells, osmotic pressure should be higher in the symplast than in the apoplast.

In most rose species, the degradation of storage carbohydrates, the import of sucrose, or both is associated with flower opening (van Doorn \& van Meeteren 2003). Young petal cells of many species contain considerable amounts of starch, which is rapidly converted to hexose (Hammond 1982; Ho \& Nichols 1977). Petal starch levels at harvest are high in many rose cultivars such as 'Sonia', but are low in cultivars such as 'Madelon' (Berkholst 1989; Gorin \& Berkholst 1982; van Doorn 1991; van Doorn \& van Meeteren 2003). Gorin and Berkholst (1982) elaborated a criterion of rose maturity for harvest, which was starch content in petals: less than $10 \%$ on DW basis would denote that flowers were picked too early. Kuiper et al. (1995) reported that adding sucrose to cut 'Madelon' rose buds induced proper flower opening, even though cut roses of this variety frequently fail to open completely under postharvest conditions, illustrating the importance of sugar accumulation in petal growth. It has also been reported that increases in glucose and fructose content during cut 'Sonia' rose opening were much greater than starch content in petals at the bud stage (Yamada et al. 2009a), suggesting that an increase in monosaccharide content cannot be attributed to only the degradation of the starch reserve. Thus, the increase in monosaccharide content derived from photosynthetic products transported from leaves seems important for proper opening in some rose cultivars. In some other flowers, including the daylily (Bieleski 1993) and Campanula rapunculoides (Vergauwen et al. 2000), fructans in the petals decrease during flower opening, which is associated with an increase in monosaccharides. 

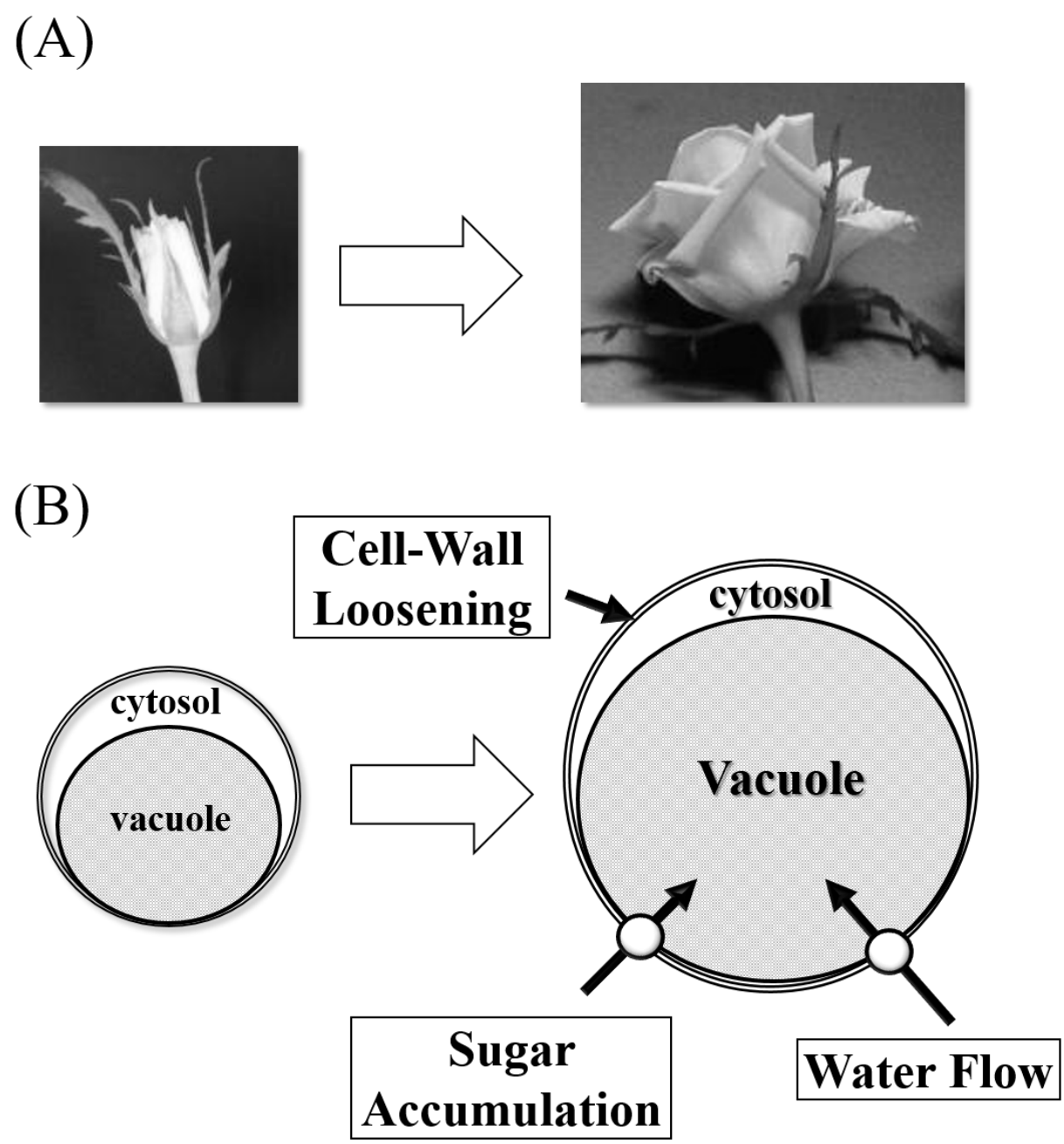

Fig. 1. Flower opening and cell enlargement of rose petal cells. Rose flower opening is a process of irreversible petal growth and reflection in which existing cells expand and fresh and dry weights increase (A). Sugar accumulation in the vacuole, cell wall loosening, and subsequent water flow into the cell are thought to be important for cell enlargement (B)

In addition to glucose, fructose, and sucrose, which are ubiquitous metabolic sugars, methyl glucoside, xylose, and myo-inositol are soluble carbohydrate constituents in roses (Ichimura et al. 1997). Myo-Inositol acts to increase osmotic pressure and is a precursor of cell wall synthesis (Loewus \& Dickinson 1982), but its application inhibits flower opening in cut roses (Ichimura et al. 1999). Myo-Inositol may accumulate in the apoplast and suppress water influx to the vacuole, leading to the inhibition of cell expansion associated with flower opening. Although the application of methyl glucoside and xylose promotes flower opening in cut roses (Ichimura et al. 1999), these carbohydrates concentrations are relatively low and do not increase during rose flower opening (Yamada et al. 2009a). Thus, these carbohydrates appear not to be important for flower opening in the rose plant.

In the shoots and leaves of some plants, $\mathrm{K}^{+}$is a primary ion that contributes to osmotic pressure, whereas $\mathrm{Ca}^{2+}, \mathrm{Mg}^{2+}, \mathrm{NO}_{3}^{-}$, and $\mathrm{Cl}^{-}$are also major ions (Cram 1976; Leigh \& Tomos 1993). In addition, organic acids contribute to the increase in osmotic pressure in many plants, such as sugarcane stalk (Cram 1976; Welbaum \& Meinzer 1990). In rose petals, malic acid and citric acid are found to be major organic acids (Biran et al. 1974; Schnabl \& Mayer 1976). Yamada et al. (2009a) determined 
the subcellular distribution of soluble carbohydrates and inorganic ions by combining nonaqueous fractionation and infiltration-centrifugation methods and showed that osmotic pressure increase in the apoplast and symplast during flower opening was mainly attributed to increases in fructose and glucose concentrations.

\section{FUNCTION OF SUGAR METABOLIZING PROTEINS DURING FLOWER OPENING}

There are two pathways of phloem unloading, that is, apoplastic or symplastic unloading pathways (Patrick \& Offler 1996). After unloading, sugars are transported through the apoplast and/or symplast. The enzymes that metabolize sucrose translocated from leaves to sink tissues are sucrose synthase and acid invertase ( $\beta$-fructofuranosidase), which are present in the vacuole (soluble form) and cell wall (insoluble form) in many higher-order plants. Acid invertase located in the cell wall converts sucrose into hexoses after sucrose is translocated from the phloem to the apoplast (Roitsch \& González 2004), and this enables petals to uptake more sucrose from the phloem. Acid invertase in the vacuole also plays an important role in sucrose metabolism. It presumably hydrolyzes sucrose to supply hexoses necessary for cell growth and development (Tang et al. 1999). In addition, invertase activities in the petals of attached rose flowers increased markedly during petal growth but not in cut roses, even in cut roses treated with sucrose (Yamada et al. 2007). On the other hand, sucrose synthase activity is weaker than acid invertase activities in rose petals (Kumar et al. 2008), suggesting that sugars appear to be transported at least partly through apoplastic unloading in rose petals. Thus, high glucose and fructose concentrations in the apoplast may be due to the transport of these carbohydrates through the apoplast (Yamada et al. 2007). In tomato (Damon et al. 1988) and apple fruits (Zhang et al. 2004), in which sugar concentrations in the apoplast are relatively high, sugars are partially transported through the apoplast. Numerous reports have indicated a relationship between invertase activity and sink strength of sink tissues (Tang et al. 1999; Balibrea et al. 2004; Roitsch \& González 2004). Invertase activity seems to limit petal growth and is related to flower opening. Some studies have shown that certain phytohormones affect invertase activity (Miyamoto et al. 1993; Trouverie et al. 2004; Pan et al. 2006; González \& Cejudo 2007). Activity of acid invertases have been shown to be affected by $\alpha$ naphthylacetic acid and methyl jasmonate treatments in cut roses, and interestingly, the speed of flower opening also changed per treatment (Horibe et al. 2013). Thus, the quality of cut rose flowers may be enhanced via controlling invertase activity postharvest.

\section{FUNCTION OF CELL-WALL-LOOSENING PROTEINS DURING FLOWER OPENING}

Relaxing the strength of the cell wall for cell enlargement is also important for petal growth (Fig. 1). When the cell walls of petals remain rigid, neither water influx nor cell expansion may occur. Cell wall extensibility may be a growth-limiting factor for petal expansion. Many proteins and enzymes are required for cell expansion. Cell-wallloosening candidate proteins include endotransglycosylase/hydrolase (XTH) and expansins (Cosgrove 2001). Expansins were first identified in cell wall protein fractions that restored acid-induced extension of heat-inactivated cell walls (McQueen-Mason et al. 1992). They are believed to disrupt hydrogen bonding between cellulose microfibrils and matrix glucans (McQueen-Mason \& Cosgrove 1994). Expansin genes belong to a multigene superfamily that includes $\alpha$-expansin, which was identified first, and $\beta$-expansin (Cosgrove 2001), which are commonly identified in expanding and growing tissues. Expansins are also expressed in non-growing tissue, such as ripening fruits (Brummel et al. 1999; Civello et al. 1999; Rose et al. 1997) and the abscission zone (Belfield et al. 2005; Sane et al. 2007). While XTHs were first identified and characterized in higher-order plants (Nishitani \& Tominaga 1992). Each gene in the XTH family catalyzes either molecular grafting or disassembly of xyloglucan cross-links within the cellulose-xyloglucan framework (Nishitani \& Tominaga 1992; Okazawa et al. 1993); thus, XTHs participate in loosening and rearranging the cell walls in growing tissues (Rose et al. 2002). XTHs may also participate in cell expansion (Nishitani 1997; Vissenberg et al. 2000). XTHs 
are expressed in growing tissues and ripening fruits as stated earlier (Catalá et al. 2000; Rose \& Bennett 1999) and in the developmental processes such as aerenchyma formation (Antosiewicz et al. 1997; Saab \& Sachs 1996).

In ornamental plants, $\alpha$ - expansin and $\beta$-expansin were identified from opening and senescing $\mathrm{Mi}$ rabilis jalapa flowers (Gookin et al. 2003). The two expansin genes are also associated with petal growth and development during carnation flower opening (Harada et al. 2011). In addition, expansin is expressed during the flower opening of tomatoes (Brummel et al. 1999) and Petunia hybrida (Zenoni et al. 2004), and XTH activity is associated with the opening of Sandersonia flowers (O'Donoghue et al. 2002). In roses, $R h E X P A$, one of the three $\alpha$-expansin genes (RhEXPA1-RhEXPA4) and RhXTH1, one of the four endotransglycosylase/hydrolase genes (RhXTH1-RhXTH4), are mainly involved in petal expansion (Takahashi et al. 2007; Yamada et al. 2009b; Dai et al. 2012). Dai et al. (2012) reported that RhEXPA4 is involved in the regulation of dehydration tolerance during the expansion of rose petals.

\section{FUNCTION OF AQUAPORINS DURING FLOWER OPENING}

Aquaporins are multifunctional membrane channels proteins that facilitate membrane transport of water molecules and low-molecular-weight compounds (Katsuhara et al. 2008). On the basis of amino acid sequence similarities, aquaporins are classified into seven subfamilies: the plasma membrane intrinsic proteins (PIPs) and tonoplast intrinsic proteins (TIPs), which are the most abundant aquaporins in the plasma membrane and tonoplast; the nodulin26-like intrinsic proteins, which are located in the peribacteroid membrane of nitrogen-fixing symbiotic root nodules of leguminous plants and are present in the plasma membrane of other species; the small basic intrinsic proteins, which are small proteins mainly localized in the membrane of endoplasmic reticulum; the uncharacterized $\mathrm{X}$ intrinsic proteins (XIPs), which are plasma membrane aquaporins that function in the transport of uncharged substrates; and the hybrid intrinsic proteins and glycerol-facilitator-like intrinsic proteins, which are present exclusively in moss (Wang et al. 2016).
Among these aquaporins, PIPs and TIPs are thought to play a key role in plant growth and cell enlargement (Katsuhara et al. 2008).

In tulips, Azad et al. (2004; 2008; 2013) suggested that petal opening and closure occur concomitantly with water transport and are regulated by reversible phosphorylation of a PIP, and two TIPs (TgTIP1;1 and TgTIP 1;2) contribute to the petal development. In the rose, it has been shown that expression of $R h-T I P 1 ; 1$ is related with ethylene and water-deficit stress reaction and RhPIPI;1 silencing significantly inhibited the expansion of petals, resulting in decreased petal size and cell area, illustrating the important role of aquaporins in the expansion of petal cell (Chen et al. 2013). As aquaporins function in the transportation of water and low-molecular-weight compounds, it is plausible that they also play an important role in flower opening. However, relatively little is known about aquaporin function in rose flower opening.

\section{CELL MORPHOLOGY OF PETAL CELLS DURING FLOWER OPENING}

In relation to the cell morphology of cut roses, adaxial and abaxial epidermal cells show marked expansion during flower opening, and adaxial epidermal cells become corn-shaped when fully opened (Yamada et al. 2009c). Differences in the patterns of cell expansion among cell types and locations, including adaxial and abaxial epidermal cells, are thought to cause petal reflection during rose flower opening. Cortical microtubules have been proposed to regulate the orientation of cell expansion (Shibaoka 1994). Ethylene inhibits longitudinal cell expansion and promotes lateral cell expansion, which is associated with changes in cortical microtubule orientation (Roberts et al. 1985; Steen \& Chadwick 1981). In some rose cultivars, ethylene accelerates flower opening (Reid et al. 1989; Tan et al. 2006) and treatment with silver thiosulfate complex, which is inhibitor of ethylene action, suppresses petal reflection (Doi 1995). Thus, the lateral growth of adaxial epidermal cells might be regulated by endogenous ethylene production by changing cortical microtubule orientation. Although exposure to ethylene at a high concentration induces petal abscission of Sonia rose (Ichimura et al. 2005; 
Reid et al. 1989), endogenous ethylene production of this cultivar is relatively low (Ichimura et al. 2005), which does not rule out the possible involvement of ethylene in the lateral cell expansion of petals.

Via light and scanning electron microscopy, the parenchyma cells of rose petals showed unique growth, resulting in a tetrapod-like shape that resembles the mesophyll cells of leaves (Yamada et al. 2009c). Mesophyll cell morphogenesis and intercellular space formation were investigated in Adiantum capillus-veneris leaves (Panteris et al. 1993) and Nigella damascena leaves (Wernicke et al. 1993). The resulting observations showed that mesophyll cell morphogenesis and intercellular space formation are controlled by highly organized cortical microtubule systems with the distribution of microtubule bundles between neighboring mesophyll cells being highly coordinated (Hellmann \& Wernicke 1998; Schröder et al. 2001; Uehara \& Hogetsu 1993). Intercellular space formation in leaves seems to make space for gas exchange in photosynthesis. Although petals are similar tissues to leaves, their functions are quite different, so the role of the air space in rose petals, in the context of flower opening, is unclear.

\section{FUNCTION OF SUGAR IN VASE WATER \\ SOLUTION AND ITS TRANSLOCATION}

The length of life in a vase, vase life, is one of the most important factors for prolonged quality of cut flowers. Vase life was shown to vary among various cultivars in carnations (Wu et al. 1991), in Gerbera (Wernett et al. 1996), and also in roses (Ichimura et al. 2002). The vase life of cut rose flowers often terminates by bending the floral axis just below the flower head, which is called bentneck. Parups and Voisey (1976) showed that thickening of the pedicel takes place at a relatively late stage in flower development and insufficient lignified pedicel lead to bent-neck. Insufficiently lignified pedicel remains rigid only because of the cell turgidity and the smallest turbulences in water balance are manifested in this region of a cut rose stem, producing bent-neck symptoms. They also reported that spraying rose shrubs with phenolic compounds before harvest could hasten lignification and prevent the phenomenon (Parups \& Voisey 1976). The development of bent-neck is also considered to be caused by vascular occlusion, which inhibits water supply to the flowers (Van Doorn 1997). Vascular occlusion is caused by the multiplication of bacteria (Van Doorn et al. 1989; Jones \& Hill 1993), air emboli (Durkin 1979), or unknown physiological responses (Marousky 1969). It has been reported that resistance to bacteria and dry storage is involved in cultivar variation in the vase life of cut roses (Van Doorn \& D'hont 1994).

Rose flowers are harvested at the bud stage, and the vase life is one of the most important characteristics. Cut roses held in water lack soluble carbohydrates that results in the suppression of petal growth and incomplete flower opening (Ichimura et al. 2003). The application of sugars to vase water improves the quality of various cut flowers, including roses (van Doorn et al. 1991; Ichimura et al. 2003). In addition, adding sucrose to cut flowers increases the levels of glucose and fructose, but it has little effect on the sucrose content in petals, indicating that sucrose translocated to petals from other organs is metabolized to glucose and fructose and thus accumulates in petal cells (Kaltaler \& Steponkus 1976). In cut rose flowers, the leaves play an important role in maintaining rates of water uptake through transpiration (Halevy \& Mayak 1981), and removal of these leaves reduces water uptake rates and causes flowers to not fully open. Mayak et al. (1974) showed that ability to close stomates in response to water stress condition was decisive factor in postharvest longevity. Adverse water relations are associated with incomplete flower opening, premature petal wilting, and bending of the pedicel in roses (Doi et al. 1999). The leaves and stems of cut flowers can also act as a source of soluble carbohydrates for the flower sink tissue. In cut chrysanthemum flowers, soluble carbohydrates accumulated in the leaves and stems were reported to affect vase life (Ishikawa et al. 2006). In cut roses, soluble carbohydrates accumulated in petals also affected vase life (Ichimura et al. 2005). Chin and Sacalis (1977) reported that 14C-sucrose, when taken up into the xylem, moved rapidly into leaves and flower heads of cut roses and that invertase located in the xylem involved in the rapid hydrolysis of sucrose. Horibe et al. (2014) showed that most of the 
exogenously applied glucose first moved to leaves, where it was converted to sucrose, and then synthesized sucrose was translocated to petals as reported in Eustoma (Shimizu-Yumoto \& Ichimura 2007), and rose and carnation (Paulin \& Jamain 1982). Plenty of soluble carbohydrates accumulate in leaves after sugar treatment, but there seems to be partial carbohydrate translocation to petals (Horibe et al. 2014). Therefore, promoting sugar translocation from leaves to petals would improve cut flower quality and elevate the positive effects of sugar treatment. More studies are still necessary to further understand the functions of leaves of cut flowers in sugar metabolism and sucrose translocation.

\section{DIURNAL RHYTHMIC GROWTH OF CUT ROSES}

Rhythmic flower opening is observed in many plant species. The existence of endogenous rhythmic opening is usually identified by placing flowers in constant darkness or constant light as the circadian clock continues despite these constant conditions (Jones \& Mansfield 1975). Some day-bloomer species and night-bloomer species have an endogenous rhythm of flower opening and closure (van Doorn \& van Meeteren 2003). However, changing from light to darkness or vice versa is necessary for flower opening in several species. The periods and amplitude of circadian rhythm are known to change without zeitgeber, such as changes of light to darkness or vice versa (Jones \& Mansfield 1975). In the Asiatic hybrid lily, flower opening has been shown to proceed irregularly if it was kept in continuous darkness, indicating the importance of changing from light to darkness for appropriate timing of flower opening (Bieleski et al. 2000). In the hybrid tea rose, Horibe et al. (2014) reported that flower opening showed a diurnal rhythm under a 12$\mathrm{h}$ photoperiod and constant dark conditions, although rhythmic flower opening under constant dark was not as clear as that of cut flowers kept under 12h light and 12-h dark cycles. However, cut roses maintained under constant light did not show rhythmic growth and kept opening slowly until fully opened. These results suggested that the rhythmic opening of cut rose flowers is influenced by changes of light to darkness or vice versa, in addition to other circadian factors. The relationship between circadian clock and hormones, light, and temperature affecting rhythmic flower opening has been well reviewed by van Doorn and Kamdee (2014). However, the mechanism of rhythmic flower opening has yet to be elucidated. Some chemical reactions, which connect the circadian oscillator and flower opening, might be halted under constant light conditions. It, therefore, seems that the opening of rose flowers needs external stimuli, a change of light to darkness or vice versa, to maintain its diurnal rhythm. Interestingly, some volatile compounds of rose flowers are emitted in a similar way. Emission of geranyl acetate oscillated under 12-h light/dark conditions but not in constant light, indicating that cyclic light and darkness are necessary for diurnal volatile emission (Hendel-Rahmanim et al. 2007). Thus, it seems that changes of light to darkness or vice versa play a key role in flower opening in plants. However, Evans and Reid (1986) reported that rhythmic opening of rose flowers was abolished upon placing flowers in continuous light or darkness, while Doi et al. (1999) reported that it was observed when flowers were exposed to constant light and darkness. These differences might result from differences between rose cultivars in the mechanism of rhythmic flower opening.

So, which endogenous mechanism governs the rhythmic opening of rose flowers? With regard to the function of carbohydrates in the diurnal rhythm of rose flower opening, Evans and Reid (1988) reported that the total carbohydrate content of petals remained constant during a light-dark cycle, indicating its importance in maintaining cell size, but it was not implicated in controlling rhythmic opening. Resistance to water movement or an inadequate water potential gradient along the transport pathway leads to limited water uptake, and the strength of the cell wall also limits cell enlargement. In tulips, petal opening and closure occur concomitantly with water transport and both are regulated by reversible phosphorylation of aquaporins (Azad et al. 2004). In addition, it has been shown that cell-wall-loosening proteins, XTH and expansins, are important in petal growth (Yamada et al. 2009b). Further explantation of the roles of these proteins in rhythmic flower opening will be an interesting and necessary avenue to pursue. 


\section{PETALS AS THE SITE OF PHOTOPERCEPTION}

Several studies have indicated that flowers are the site of photoperception and perceive red or/and blue light (Saito \& Yamaki 1967; Kaihara \& Takimoto 1980, 1981a, b). In Calendula arvensis, its flower opening and closing circadian rhythm followed the light-dark cycle in a manner dependent upon which flower had been exposed when the leaves were subjected to a different light-dark cycle from the flowers (van Doorn \& van Meeteren 2003). In cut roses, rose petals can perceive red and blue light and synchronize their growth to photoperiods (Horibe \& Yamada 2014a; Horibe \& Yamada 2014b; Horibe et al. 2014), but it is still unclear which photoreceptors play a role in receiving red and blue light and what reactions are involved between perception of light and rhythmic flower opening. Another report showed that a relatively slow phytochrome reaction is involved in the perception of the duration of light or darkness (Lumsden 1991). Such a reaction might also be involved in light perception in roses; however, it is still not clear which wavelength is effective and which photoreceptor perceives light in rose petals.

There are many reports showing that the light condition affects several aspects of plant physiology, including flower opening and volatile emission (Hendel-Rahmanim et al. 2007; Kaihara \& Takimoto 1980, 1981a, b). Red and blue light seem to be perceived in petals and affect flower opening and closing in some species. In Oenothera lamarckiana, flower opening was arrested by light, and it was only effective when the wavelength was between 400 and $510 \mathrm{~nm}$, which is, respectively, the blue and green regions of the visible spectrum (Saito \& Yamaki 1967). Furthermore, red light was shown to promote flower opening, but its effect was reversed by a subsequent exposure to far-red light in Ipomoea nil (Kaihara \& Takimoto 1980, 1981a, b). In roses, it has been reported that the speed of flower opening was delayed in cut flowers exposed to red and blue light compared with those exposed to white light (Horibe \& Yamada 2014b), suggesting that exposing cut flowers to specific wavelengths of light might be useful for controlling flower opening. Thus, understanding a cut rose flower's response to light stimuli might lead to the development of a new method to improve quality. In addition, there is a possibility that light increases petal temperature by being absorbed by pigments in the petals, resulting in the promotion of petal growth. Depending on petal anatomy and pigmentation, light can indeed increase petal temperature (McKee \& Richards 1998). In Portulaca plants, a rise in temperature resulted in rapid flower opening, although light also intensified the response (Ichimura \& Suto 1998). Changes in temperature of petals might also affect petal growth of cut rose flowers.

\section{CONCLUSION AND FUTURE PROSPECTS}

In this review, we described cell morphology, sugar metabolism, cell-wall-loosening proteins, aquaporins, the mechanism of rhythmic flower opening, and the perception of light in the context and landscape of cut rose flower opening. However, future research is warranted in these outlined topics as well as in-depth analysis of their interrelatedness and impact on cut rose flower opening and quality. Until now, most research has focused on senescence to improve the vase life of flowers, leading to the invention of and utility of ethylene production/action inhibitors. However, few studies have focused on the physiology of petal growth, the perception of light by petals, and the relationship between petal growth and environmental conditions. Elucidation of the mechanisms of flower opening would contribute to enhanced quality and commercial production of floricultural crops as well as greatly advance basic scientific knowledge regarding plant biology.

\section{REFERENCES}

Antosiewicz D.M., Purugganan M.M., Polisensky D.H., Braam J. 1997. Cellular localization of Arabidopsis xyloglucan endotransglycosylase-related proteins during development and after wind stimulation. Plant Physiology 115: 1319-1328. DOI: 10.1104/pp.115.4.1319.

Azad A.K., Sawa Y., Ishikawa T., Shibata H. 2004. Phosphorylation of plasma membrane aquaporin regulates temperature-dependent opening of tulip petals. Plant and Cell Physiology 45: 608-617. DOI: 10.1093/pcp/pch069.

Azad A.K., Katsuhara M., Sawa Y., Ishikawa T., Shibata H. 2008. Characterization of four plasma membrane 
aquaporins in tulip petals: a putative homolog is regulated by phosphorylation. Plant and Cell Physiology 49: 1196-208. DOI: 10.1093/pcp/pcn095.

Azad A.K., Hanawa R., Ishikawa T., Sawa Y., Shibata H. 2013. Expression profiles of aquaporin homologues and petal movement during petal development in Tulipa gesneriana. Physiologia Plantarum 148: $397-$ 407. DOI: 10.1111/j.1399-3054.2012.01717.x.

Balibrea Lara M.E., Gonzalez Garcia M-C., Fatima T., Ehneß R., Lee T.K., Proels R. et al. 2004. Extracellular invertase is an essential component of cytokinin-mediated delay of senescence. Plant Cell 16: 1276-1287. DOI: 10.1105/tpc.018929.

Belfield E.J., Ruperti B., Roberts J.A., McQueen-Mason S.J. 2005. Changes in expansin activity and gene expression during ethylene-promoted leaflet abscission in Sambucus nigra. Journal of Experimental Botany 56: 817-823. DOI: 10.1093/jxb/eri076.

Bendahmane M., Dubois A., Raymond O., Bris M.L. 2013. Genetics and genomics of flower initiation and development in roses. Journal of Experimental Botany 64: 847-857. DOI: 10.1093/jxb/ers387.

Berkholst C.E.M. 1989. High starch content in 'Sonia' rose corollas at picking may add quality to vase life. Gartenbauwissenschaft 54: 9-10.

Bieleski R.L. 1993. Fructan hydrolysis drives petal expansion in the ephemeral daylily flower. Plant Physiology 103: 213-219. DOI: 10.1104/pp.103.1.213.

Biran M., Robinson M., Halevy A.H. 1974. Factors determining petal color of Baccara roses. Journal of Experimental Botany 25: 624-663. DOI: 10.1093/jxb/25.4.624.

Bieleski R., Elgar J., Heyes J., Woolf A. 2000. Flower opening in Asiatic lily is a rapid process controlled by dark-light cycling. Annals of Botany 86: 11691174. DOI: $10.1006 /$ anbo.2000.1289.

Burdett A.N. 1970. The cause of bent neck in cut roses. Journal of the American Society for Horticultural Science 95: 427-431.

Brummel D.A., Harpster M.H., Dunsmuir P. 1999. Differential expression of expansin gene family members during growth and ripening of tomato fruit. Plant Molecular Biology 39: 161-169. DOI: 10.1023/A:1006130018931.

Catalá C., Rose J.K.C., Bennett A.B. 2000. Auxin-regulated genes encoding cell wall-modifying proteins are expressed during early tomato fruit growth. Plant Physiology 122: 527-534. DOI: 10.1104/pp.122.2.527.

Chen W., Yin X., Wang L., Tian J., Yang R., Liu D. et al. 2013. Involvement of rose aquaporin RhPIP1;1 in ethylene-regulated petal expansion through interaction with RhPIP2;1. Plant Molecular Biology 83: 219-233. DOI: 10.1007/s11103-013-0084-6.

Chin C., Sacalis J.N. 1977. Metabolism of sucrose in cut roses. II. Movement and inversion of sucrose absorbed by cyt rose stems. Journal of the American Society for Horticultural Science 102: 537-540.

Cosgrove D.J. 2001. Wall structure and wall loosening. A look backwards and forwards. Plant Physiology 125: 131-134. DOI: 10.1104/pp.125.1.131.

Civello P.M., Powell A.L.T., Sabehat A., Bennett A.B. 1999. An expansin gene expressed in ripening strawberry fruit. Plant Physiology 121: 1273-1279. DOI: 10.1104/pp.121.4.1273.

Cram W.J. 1976. Negative feedback regulation of transport in cells. The maintenance of turgor, volume and nutrient supply. In: Lüttge U., Pitman M.G. (Eds.), Encyclopedia of plant physiology, Transport in plants II, pp. 284-316. DOI: 10.1007/978-3-642-66227-0_11.

Dai F., Zhang C., Jiang X., Kang M., Yin X., Lü P. et al. 2012. RhNAC2 and RhEXPA4 are involved in the regulation of dehydration tolerance during the expansion of rose petals. Plant Physiology 160: 2064 2082. DOI: 10.1104/pp.112.207720.

Damon S., Hewitt J., Nieder M., Bennett A. 1988. Sink metabolism in tomato fruit. II. Phloem unloading and sugar uptake. Plant Physiology 87: 731-736. DOI: 10.1104/pp.87.3.731.

de Stigter H.C.M. 1980. Water balance of cut and intact Sonia rose plants. Zeitschrift für Pflanzenphysiologie 99: 131-140. DOI: 10.1016/s0044-328x(80)80122-x.

Doi M. 1995. Flower durability. In: Nogyo Gijutsu Taikei, Kakihen, vol. 3. Nobunkyo, Tokyo, pp. 105-109. [in Japanese with English abstract]

Doi M., Miyagawa Namao M., Inamoto K., Imanishi H. 1999. Rhythmic changes in water uptake, transpiration and water potential of cut roses as affected by photoperiods. Journal of the Japanese Society for Horticultural Science 68: 861-867. DOI: 10.2503/jjshs.68.861. [in Japanese with English abstract]

Durkin D.J. 1979. Effect of Millipore filtration, citric acid, and sucrose on peduncle water potential of cut rose flower. Journal of the American Society for Horticultural Science 104: 860-863.

Evans R.Y., Reid M.S. 1986. Control of petal expansion during diurnal opening of roses. Acta Horticulturae 181: 55-63. DOI: 10.17660/ActaHortic.1986.181.5.

Evans R.Y., Reid M.S. 1988. Changes in carbohydrates and osmotic potential during rhythmic expansion of 
rose petals. Journal of the American Society for Horticultural Science 113: 884-888.

Faragher J.D., Mayak S., Tirosh T., Halevy A.H. 1984. Cold storage of rose flowers: Effects of cold storage and water loss on opening and vase life of 'Mercedes' roses. Scientia Horticulturae 24: 369-378. DOI: 10.1016/0304-4238(84)90122-5.

González M-C., Cejudo F.J. 2007. Gibberellin-regulated expression of neutral and vacuolar invertase genes in petioles of sugar beet plants. Plant Science 172: 839-846. DOI: 10.1016/j.plantsci.2007.01.001.

Gookin T.E., Hunter D.A., Reid M.S. 2003. Temporal analysis of alpha- and beta-expansin expression during floral opening and senescence. Plant Science 164: 769-781. DOI: 10.1016/S0168-9452(03)00063-3.

Gorin N., Berkholst C.E.M. 1982. Starch in petals of cut roses cv. Sonia as possible criterion of picking. Gartenbauwissenschaft 47: 75-77.

Halevy A.H., Mayak S. 1981. Senescence and postharvest physiology of cut flowers: Part 2. Horticultural Reviews 3: 59-143. DOI: 10.1002/9781118060766.ch3.

Hammond J.B.W. 1982. Changes in amylase activity during rose bud opening. Scientia Horticulturae 16: 283-289. DOI: 10.1016/0304-4238(82)90076-0.

Harada T., Torii Y., Morita S., Onodera R., Hara Y., Yokoyama R. et al. 2011. Cloning, characterization, and expression of xyloglucan endotransglucosylase/hydrolase and expansin genes associated with petal growth and development during carnation flower opening. Journal of Experimental Botany 62: 815823. DOI: $10.1093 /$ jxb/erq319.

Hellmann A., Wernicke W. 1998. Changes in tubulin protein expression accompany reorganization of microtubular arrays during cell shaping in barley leaves. Planta 204: 220-225. DOI: 10.1007/s004250050250.

Hendel-Rahmanim K., Masci T., Vainstein A., Weiss D. 2007. Diurnal regulation of scent emission in rose flowers. Planta 226: 1491-1499. DOI: 10.1007/s00425-007-0582-3.

Ho L.C., Nichols R. 1977. Translocation of ${ }^{14} \mathrm{C}$-sucrose in relation to changes in carbohydrate content in rose corollas cut at different stages of development. Annals of Botany 41: 227-242. DOI: 10.1093/oxfordjournals.aob.a085272.

Horibe T., Yamaki S., Yamada K. 2013. Effects of auxin and methyl jasmonate on cut rose petal growth through activation of acid invertase. Postharvest Biology and Technology 86: 195-200. DOI: 10.1016/j.postharvbio.2013.06.033.
Horibe T., Yamada K. 2014a. Petals of cut rose flower show diurnal rhythmic growth. Journal of the Japanese Society for Horticultural Science 83: 302-307. DOI: $10.2503 /$ jjshs1.ch-101.

Horibe T., Yamada K. 2014b. Diurnal rhythm of petal growth in cut rose flowers. Acta Horticulturae 1064: 241-245. DOI: 10.17660/ActaHortic.2015.1064.27.

Horibe T., Yamaki S., Yamada K. 2014. Leaves of cut rose flower convert exogenously applied glucose to sucrose and translocate it to petal. Journal of Horticultural Research 22: 41-46. DOI: 10.2478/johr-2014-0020.

Ichimura K., Kohata K., Koketsu M., Yamaguchi Y., Yamaguchi H., Suto K. 1997. Identification of methyl ß-glucopyranoside and xylose as soluble sugar constituents in roses (Rosa hybrida L.). Bioscience, Biotechnology, and Biochemistry 61: 1734-1735. DOI: $10.1271 / \mathrm{bbb} .61 .1734$.

Ichimura K., Suto K. 1998. Environmental factors controlling flower opening and closing in a Portulaca hybrid. Annals of Botany 82: 67-70. DOI: 10.1006/anbo.1998.0642.

Ichimura K., Mukasa Y., Fujiwara T., Kohata K., Goto R., Suto K. 1999. Possible roles of methyl glucoside and myoinositol in the opening of cut rose flowers. Annals of Botany 83: 551-557. DOI: 10.1006/anbo.1999.0856.

Ichimura K., Kawabata Y., Kishimoto M., Goto R., Yamada K. 2002. Variation with the cultivar in the vase life of cut rose flowers. Bulletin of National Institute of Floriculture Sciences 2: 9-20.

Ichimura K., Kawabata Y., Kishimoto M., Goto R., Yamada K. 2003. Shortage of soluble carbohydrates is largely responsible for short vase life of cut 'Sonia' rose flowers. Journal of the Japanese Society for Horticultural Science 72: 292-298. DOI: $10.2503 /$ jjshs.72.292.

Ichimura K., Kishimoto M., Norikoshi R., Kawabata Y., Yamada K. 2005. Soluble carbohydrates and variation in vaselife of cut rose cultivars 'Delilah' and 'Sonia'. Journal of Horticultural Science and Biotechnology 80: 280-286. DOI: 10.1080/14620316.2005.11511930.

Ichimura K., Shimizu-Yumoto H. 2007. Extension of the vase life of cut roses by treatment with sucrose before and during simulated transport. Bulletin of $\mathrm{Na}-$ tional Institute of Floriculture Sciences 7: 17-27.

Ishikawa T., Nishio J., Ichimura K. 2006. Effects of light shielding treatment during cultivation on vase life and sugar content of cut chrysanthemum. Research 
Bulletin of the Aichi-ken Agricultural Research Center 38: 127-132.

Jones M.B., Mansfield T.A. 1975. Circadian rhythms in plants. Science Progress 62: 103-125.

Jones R.B., Hill M. 1993. The effect of germicides on the longevity of cut flowers. Journal of the American Society for Horticultural Science 118: 350-354.

Kaihara S., Takimoto A. 1980. Studies on the light controlling the time of flower-opening in Pharbitis nil. Plant and Cell Physiology 21: 21-26.

Kaihara S., Takimoto A. 1981a. Effects of light and temperature on flower-opening in Pharbitis nil. Plant and Cell Physiology 22: 215-221.

Kaihara S., Takimoto A. 1981b. Physical basis of flower opening in Pharbitis nil. Plant and Cell Physiology 22: $307-310$

Kaltaler R.E.L., Steponkus P.L. 1976. Factors affecting respiration in cut roses. Journal of the American Society for Horticultural Science 101: 352-354.

Katsuhara M., Hanba Y.T., Shiratake K., Maeshima M. 2008. Expanding roles of plant aquaporins in plasma membranes and cell organelles. Functional Plant Biology 35: 1-14. DOI: 10.1071/FP07130.

Kenis J.D., Silvents S.T., Trippi V.S. 1985. Nitrogen metabolite and senescence-associated change during growth of carnation flowers. Physiologia Plantarum 65: 455459. DOI: 10.1111/j.1399-3054.1985.tb08673.x.

Koning R.E. 1984. The role of plant hormones in the growth of the corolla of Gaillardia grandiflora (Asteraceae) ray flowers. American Journal of Botany 71: 1-8. DOI: 10.2307/2443617.

Kuiper D., Ribot S., Van Reenen H.S., Marissen N. 1995. The effect of sucrose on the flower bud opening of 'Madelon' cut roses. Scientia Horticulturae 60: 325-336. DOI: 10.1016/0304-4238(94)00706-1.

Kumar N., Srivastava G.C., Dixit K. 2008. Role of sucrose synthase and invertase during petal senescence in rose (Rosa hybrid L.). Journal of Horticultural Science and Biotechnology 83: 520-524. DOI: 10.1080/14620316.2008.11512416.

Leigh R.A., Tomos A.D. 1993. Ion distribution in cereal leaves: pathways and mechanisms. Philosophical Transactions of the Royal Society, B: Biological Sciences 341: 75-86. DOI: 10.1098/rstb.1993.0093.

Loewus F.A., Dickinson D.B. 1982. Cyclitols. In: Loewus F.A., Tanner W. (Eds.), Encyclopedia of plant physiology, N.S., vol 13A: plant carbohydrates I. Springer, Berlin, pp. 193-216.

Lumsden P.J. 1991. Circadian rhythms and phytochrome. Annual Review of Plant Physiology and
Plant Molecular Biology 42: 351-371. DOI: 10.1146/annurev.pp.42.060191.002031.

Ma N., Tan H., Liu X., Xue J., Li Y., Gao J. 2006. Transcriptional regulation of ethylene receptor and CTR genes involved in ethylene-induced flower opening in cut rose (Rosa hybrida) cv. Samantha. Journal of Experimental Botany 57: 2763-2773. DOI: 10.1093/jxb/erl033.

Ma N., Xue J., Li Y., Liu X., Dai F., Jia W. et al. 2008. $\mathrm{Rh}-\mathrm{PIP} 2 ; 1$, a rose aquaporin gene, is involved in ethylene-regulated petal expansion. Plant Physiology 148: 894-907. DOI: 10.1104/pp.108.120154.

Macnish A.J., Leonard R.T., Borda A.M., Nell T.A. 2010. Genetic variation in the postharvest performance and ethylene sensitivity of cut rose flowers. HortScience 45: 790-796.

Marousky F.J. 1969. Vascular blockage, water absorption, stomatal opening, and respiration of cut 'Better times' roses treated with 8-hydroxiquinoline citrate and sucrose. Journal of the American Society for Horticultural Science 94: 223-226.

Mayak S., Halevy A.H., Sagie S., Bar-Yoseph A., Bravdo B. 1974. The water balance of cut rose flowers. Physiologia Plantarum 31: 15-22. DOI: 10.1111/j.1399-3054.1974.tb03671.x.

McKee J., Richards A.J. 1998. Effect of flower structure and flower colour on intrafloral warming, pollen germination and pollen tube growth in winter-flowering Crocus L. (Iridaceae). Botanical Journal of the Linnean Society 128: 369-384. DOI: 10.1111/j.1095-8339.1998.tb02127.x.

McQueen-Mason S.J., Durachko D.M., Cosgrove D.J. 1992. Two endogenous proteins that induce cellwall extension in plants. Plant Cell 4: 1425-1433. DOI: $10.1105 /$ tpc.4.11.1425.

McQueen-Mason S.J., Cosgrove D.J. 1994. Disruption of hydrogen-bonding between plant-cell wall polymers by proteins that induce wall extension. Proceedings of the National Academy of Sciences USA 91: 6574-6578. DOI: 10.1073/pnas.91.14.6574.

Miyamoto K., Ueda J., Kamisaka S. 1993. Gibberellinenhanced sugar accumulation in growing subhooks of etiolated Pisum sativum seedlings. Effects of gibberellic acid, indoleacetic acid and cycloheximide on invertase activity, sugar accumulation and growth. Physiologia Plantarum 88: 301-306. DOI: 10.1111/j.1399-3054.1993.tb05503.x.

Nishitani K., Tominaga R. 1992. Endo-xyloglucan transferase, a novel class of glycosyltransferase that catalyzes transfer of a segment of xyloglucan molecule to another xyloglucan molecule. Journal of $\mathrm{Bi}$ ological Chemistry 267: 21058-21064. 
Nishitani K. 1997. The role of endoxyloglucan transferase in the organization of plant cell walls. International Review of Cytology 173: 157-206. DOI: 10.1016/S0074-7696(08)62477-8.

O’Donoghue E.M., Somerfield S.D., Heyes J.A. 2002. Organization of cell walls in Sandersonia aurantiaca floral tissue. Journal of Experimental Botany 53: 513-523. DOI: 10.1093/jexbot/53.368.513.

Okazawa K., Sato Y., Nakagawa T., Asada K., Kato I., Tomita E., Nishitani K. 1993. Molecular cloning and cDNA sequencing of endoxyloglucan transferase, a novel class of glycosyltransferase that mediates molecular grafting between matrix polysaccharides in plant cell walls. Journal of Biological Chemistry 268: 25364-25368.

Pan Q-H., Yu X-C., Zhang N., Zou X., Peng C-C., Wang $\mathrm{X}-\mathrm{L}$. et al. 2006. Activity, but not expression, of soluble and cell wall-bound acid invertase is induced by abscisic acid in developing apple fruit. Journal of Integrative Plant Biology 48: 536-549. DOI: 10.1111/j.1744-7909.2006.00251.x.

Panteris E., Apostolakos P., Galatis B. 1993. Microtubule organization, mesophyll cell morphogenesis, and intercellular space formation in Adiantum capillus veneris leaflets. Protoplasma 172: 97-110. DOI: 10.1007/bf01379367.

Parups E.V., Voisey P.W. 1976. Lignin content and resistance to bending of the pedicel in greenhouse grown roses. Journal of Horticultural Science 51: 253-259. DOI: 10.1080/00221589.1976.11514688.

Patrick J.W., Offler C.E. 1996. Post-sieve element transport of photoassimilates in sink regions. Journal of Experimental Botany 47: 1165-1177. DOI: 10.1093/jxb/47.Special_Issue.1165.

Paulin A. 1979. Évolucion comparée des glucides dans les divers organs de la rose coupée (var. Carina) alimentée temporairement avec une solution glucosée. Physiologie Végétale 17: 129-143.

Paulin A., Jamain C. 1982. Development of flowers and changes in various sugars during opening of cut carnations. Journal of the American Society for Horticultural Science 107: 258-261.

Reid M.S., Evans R.Y. 1986. Control of cut flower opening. Acta Horticulturae 181: 45-54. DOI: 10.17660/ActaHortic.1986.181.4.

Reid M.S., Dodge L.L., Mor Y., Evans R.Y. 1989. Effects of ethylene on rose opening. Acta Horticulturae 261: 215-220.

Reid M.S., Evans R.Y., Dodge L.L., Mor Y. 1989. Ethylene and silver thiosulfate influence opening of cut rose flowers. Journal of the American Society for Horticultural Science 114: 436-440.

Roberts I.N., Lloyd C.W., Roberts K. 1985. Ethylene-induced microtubule reorientations: mediation by helical arrays. Planta 164: 439-447. DOI: 10.1007/BF00395959.

Roitsch T., González M-C. 2004. Function and regulation of plant invertases: sweet sensations. Trends in Plant Science 9: 606-613. DOI: 10.1016/j.tplants.2004.10.009.

Rose J.K.C., Lee H.H., Bennett A.B. 1997. Expression of a divergent expansin gene is fruit-specific and ripeningregulated. Proceedings of the National Academy of Sciences USA 94: 5955-5960.

Rose J.K.C., Bennett A.B. 1999. Cooperative disassembly of the cellulose-xyloglucan network of plant cell walls: parallels between cell expansion and fruit ripening. Trends in Plant Science 4: 176-183. DOI: 10.1016/S1360-1385(99)01405-3.

Rose J.K.C., Braam J., Fry S.C., Nishitani K. 2002. The XTH family of enzymes involved in xyloglucan endotransglucosylation and endohydrolysis: current perspectives and a new unifying nomenclature. Plant and Cell Physiology 43: 1421-1435. DOI: $10.1093 / \mathrm{pcp} / \mathrm{pcf} 171$.

Roberts A.V., Debener T., Gudin S. 2003. Elsevier Academic Press, Amsterdam. Encyclopedia of rose science, $1^{\text {st }}$ ed., vol. 2, pp. 504-512.

Saab I.N., Sachs M.M. 1996. A flooding-induced xyloglucan endo-transglycosylase homolog in maize is responsive to ethylene and associated with aerenchyma. Plant Physiology 112: 385-391. DOI: 10.1104/pp.112.1.385.

Saito M., Yamaki T. 1967. Retardation of flower opening in Oenothera lamarckiana caused by blue and green light. Nature 214: 1027. DOI: 10.1038/2141027a0.

Sane A.P., Tripathi S.K., Nath P. 2007. Petal abscission in rose (Rosa bourboniana var Gruss an Teplitz) is associated with the enhanced expression of an alpha expansin gene, RbEXPA1. Plant Science 172: 481-487. DOI: 10.1016/j.plantsci.2006.10.005.

Schnabl H., Mayer I. 1976. Dark fixation of $\mathrm{CO}_{2}$ by flowers of cut roses. Planta 131: 51-55. DOI: 10.1007/BF00387345.

Schröder J., Stenger H., Wernicke W. 2001. $\alpha$-Tubulin genes are differentially expressed during leaf cell development in barley (Horgeum vulgare L.). Plant Molecular Biology 45: 723-730. DOI: 10.1023/A:1010648519206.

Shibaoka H. 1994. Plant hormone-induced changes in the orientation of cortical microtubules: Alterations in 
the cross-linking between microtubules and the plasma membrane. Annual Review of Plant Physiology and Plant Molecular Biology 45: 527-544. DOI: 10.1146/annurev.pp.45.060194.002523.

Shimizu-Yumoto H., Ichimura K. 2007. Effect of relative humidity and sucrose concentration on leaf injury and vase-life during sucrose pulse treatment in cut Eustoma flowers. Horticultural Research (Japan) 6: 301-305. DOI: 10.2503/hrj.6.301.

Steen D.A., Chadwick A.V. 1981. Ethylene effects in pea stem tissue. Evidence of microtubule mediation. Plant Physiology 67: 460-466. DOI: 10.1104/pp.67.3.460.

Takahashi R., Fujitani C., Yamaki S., Yamada K. 2007. Analysis of the cell wall loosening proteins during rose flower opening. Acta Horticulturae 755: 483 488. DOI: 10.17660/ActaHortic.2007.755.66.

Tang G.Q., Lüscher M., Sturm A. 1999. Antisense repression of vacuolar and cell wall invertase in transgenic carrot alters early plant development and sucrose partitioning. Plant Cell 11: 177-189. DOI: 10.1105/tpc.11.2.177.

Tan H., Liu D., Ma N., Xue J., Lu W., Bai J., Gao J. 2006. Ethylene-influenced flower opening and expression of genes encoding ETRs, CTRs, and EIN3s in two rose cultivars. Postharvest Biology and Technology 40: 97105. DOI: 10.1016/j.postharvbio.2006.01.007.

Trouverie J., Chateau-Joubert S., Thévenot C., Jacquemot M.-P., Prioul J.-L. 2004. Regulation of vacuolar invertase by abscisic acid or glucose in leaves and roots from maize plantlets. Planta 219: 894-905. DOI: 10.1007/s00425-004-1289-3.

Uehara U., Hogetsu T. 1993. Arrangement of cortical microtubules during formation of bordered pit in the tracheids of Texus. Protoplasma 172: 145-153. DOI: 10.1007/BF01379372.

van Doorn W.G., Schurer K., Witte Y.D. 1989. Role of endogenous bacteria in vascular blockage of cut rose flowers. Journal of Plant Physiology 134: 375 381. DOI: 10.1016/S0176-1617(89)80259-7.

van Doorn W.G., D'hont K. 1994. Interaction between the effects of bacteria and dry storage on the opening and water relations of cut rose flowers. Journal of Applied Bacteriology 77: 644-649. DOI: 10.1111/j.1365-2672.1994.tb02814.x.

van Doorn W.G. 1997. Water relations of cut flowers. Horticultural Reviews 18: 1-85.

van Doorn W.G., Groenewegen G., van de Pol P.A., Berkholst C.E.M. 1991. Effects of carbohydrates and water status on opening of cut Madelone roses. Postharvest Biology and Technology 1: 47-57. van Doorn W.G., van Meeteren U. 2003. Flower opening and closure: a review. Journal of Experimental Botany 54: 1801-1812. DOI: 10.1093/jxb/erg213.

van Doorn W.G., Kamdee C. 2014. Flower opening and closure: an update. Journal of Experimental Botany 65: 5749-5757. DOI: 10.1093/jxb/eru327.

Vergauwen R., van den Ende W., van Laere A. 2000. The role of fructan in flowering of Campanula rapunculoides. Journal of Experimental Botany 51: 1261-1266. DOI: 10.1093/jexbot/51.348.1261.

Vissenberg K., Martinez-Vilchez I.M., Verbelen J.-P., Miller J.G., Fry S.C. 2000. In vivo colocalization of xyloglucan endotransglycosylase activity and its donor substrate in the elongation zone of Arabidopsis roots. Plant Cell 12: 1229-1238. DOI: 10.1105/tpc.12.7.1229.

Wagner G.J. 1979. Content and vacuole/extravacuole distribution of neutral sugars, free amino acids, and anthocyanin in protoplasts. Plant Physiology 64: 88-93. DOI: 10.1104/pp.64.1.88.

Wang M., Ding L., Gao L., Li Y., Shen Q., Guo S. 2016. The interactions of aquaporins and mineral nutrients in higher plants. International Journal of Molecular Sciences 17: 1229. DOI: 10.3390/ijms17081229.

Welbaum G.E., Meinzer F.C. 1990. Compartmentation of solutes and water in developing sugarcane stalk tissue. Plant Physiology 93: 1147-1153. DOI: 10.1104/pp.93.3.1147.

Wernett H.C., Wilfret G.J., Sheehan T.J., Marousky F.J., Lyrene P.M., Knauft D.A. 1996. Postharvest longevity of cut-flower Gerbera. I. Response to selection for vase life of components. Journal of the American Society for Horticultural Science 121: 216-221.

Wernicke W., Günther P., Jung G. 1993. Microtubules and cell shaping in the mesophyll of Nigella damascena L. Protoplasma 173: 8-12. DOI: 10.1007/BF01378857.

Wu M.J., van Doorn W.G., Reid M.S. 1991. Variation in the senescence of carnation (Dianthus caryophyllus L.) cultivars. I. Comparison of flower life, respiration and ethylene biosynthesis. Scientia Horticulturae 48: 99107. DOI: 10.1016/0304-4238(91)90156-s.

Yamada K., Ito M., Oyama T., Nakada M., Maesaka M., Yamaki S. 2007. Analysis of sucrose metabolism during petal growth of cut roses. Postharvest Biology and Technology 43: 174-177. DOI: 10.1016/j.postharvbio.2006.08.009.

Yamada K., Norikoshi R., Suzuki K., Imanishi H., Ichimura K. 2009a. Determination of subcellular concentrations of soluble carbohydrates in rose petals during opening by nonaqueous fractionation method combined with 
infiltration-centrifugation method. Planta 230: 1115 1127. DOI: 10.1007/s00425-009-1011-6.

Yamada K., Takahashi R., Fujitani C., Mishima K., Yoshida M., Daryl C.J., Yamaki S. 2009b. Cell wall extensibility and effect of cell-wall-loosening proteins during rose flower opening. Journal of the Japanese Society for Horticultural Science 78: 242251. DOI: 10.2503/jjshs1.78.242.

Yamada K., Norikoshi R., Suzuki K., Nishijima T., Imanishi H., Ichimura K. 2009c. Cell division and expansion growth during rose petal development. Journal of the Japanese Society for Horticultural
Science 78: 356-362. DOI: 10.2503/jjshs1.78.356. Zenoni S., Reale L., Tornielli G.B., Lanfaloni L., Porceddu A., Ferrarini A. et al. 2004. Downregulation of the Petunia hybrida $\alpha$-expansin gene $P h E X P 1$ reduces the amount of crystalline cellulose in cell walls and leads to phenotypic changes in petal limbs. Plant Cell 16: 295-308. DOI: 10.1105/tpc.018705.

Zhang L.Y., Peng Y.B., Pelleschi-Travier S., Fan Y., Lu Y.F., Lu Y.M. et al. 2004. Evidence for apoplasmic phloem unloading in developing apple fruit. Plant Physiology 135: 574-86. DOI: 10.1104/pp.103.036632. 